\title{
Evaluation of dry matter yield and nutritive value of Sugar graze and Jumbo plus at different spacing in the yala season in the dry zone of Sri Lanka
}

\author{
Sagana Pushparajah and Jeyalingawathani Sinniah*
}

\begin{abstract}
Background: A field experiment to evaluate the dry matter yield and nutritive value of Sugar graze and Jumbo plus under irrigation was conducted at three different plant spacings $(15 \times 30,15 \times 45,15 \times 60 \mathrm{~cm})$ on a red-yellow latosol in the dry zone of Sri Lanka from March to June 2016. The design was a factorial randomised complete block design with three replications. Morphological parameters measured were plant height, leaf length, leaf width, leaf area and number of leaves per plant, inter-node elongation and stem girth. Chemical composition of forages, viz. crude protein, crude fibre, neutral detergent fibre, acid detergent fibre and dry matter yield, was also determined.
\end{abstract}

Results: There was no difference in the chemical composition of Sugar graze and Jumbo plus 60 days after planting. Sugar graze had significantly higher values $(p<0.05)$ for stem girth, leaf length, leaf width and leaf area 60 days after planting. Sugar graze produced significantly higher dry matter yield than Jumbo plus. The narrowest spacing $15 \times 30 \mathrm{~cm}$ gave the highest yield than the other 2 spacings.

Conclusions: It could be concluded that Sugar graze with $15 \times 30 \mathrm{~cm}$ spacing will give more dry matter yield than Jumbo plus with similar chemical composition in the yala season of dry zone of Sri Lanka.

Keywords: Crude fibre, Crude protein, Neutral detergent fibre, Acid detergent fibre

\section{Background}

The performance of dairy animals depends on the consistent availability of quality fodder in adequate amount. Therefore, the critical limitation on profitable animal production in developing countries is the inadequacy of quality forage [1]. In many developing countries, because of ever growing human need for food, only limited cultivated land can be allocated to fodder production.

Most tropical grasses, like Guinea, Brachiaria and Napier, have high fibre content and low sugar and protein content. This affects the intake and digestibility of the grass, and most of the indigestible portions are passed as excreta. Furthermore, the critical lack of protein in many

*Correspondence: jeyalingawathani@gmail.com Department of Animal Science, Faculty of Agriculture, University of Jaffna, Ariviyal Nagar, Kilinochchi, Sri Lanka of these grasses directly limits the ability of the cow to produce milk.

In contrast, grasses like Sugar graze (sorghum), maize and improved Napier variants $(\mathrm{CO}-3$ and $\mathrm{CO}-4)$ are considered high-quality cattle feed because of the nutritive value they bring. Among these grasses, sorghum and maize are high-energy sources when compared with the improved Napier varieties. While they are high in nutritive value, maize and improved Napier variants (CO-3 and $\mathrm{CO}-4$ ) require a considerable amount of water for cultivation. In addition, maize can only be cut once while sorghum can be cut 4-5 times with one planting. Considering its nutritive value, production capacity and profitability, sorghum brings more benefit to farmers [2].

In arid and semi-arid areas of the world, water is the principal limiting factor of agricultural production primarily due to low and/or uneven distributions of annual 
rainfall $[3,4]$. Pearl millet (Pennisetum miliaceum L.) and sorghum (Sorghum bicolor L.) are important forages in several arid and semi-arid regions of the world and are well adapted to environments with limited rainfall, high temperatures and low soil fertility $[5,6]$. It has been shown that sorghum and millet were more drought resistant and have higher water-use efficiency compared with corn and are able to produce acceptable forage yields when exposed to drought $[7,8]$.

Sorghum (Sorghum bicolor (L) Moench) is an annual crop grown in the summer season for fodder production and is considered the fifth major cereal in terms of area and production in the world [9]. Recently, some varieties of this crop evolved as the hybrids by crossing between sorghum (Sorghum bicolor (L) Moench) and Sudan grass (Sorghum bicolor subsp. drummondii) that are known for their quick growth, multi-cuts and nutritious fodder with higher total digestive nutrients (TDN) and crude protein (CP) values exceeding $53-60 \%$ and $9-15 \%$, respectively [10]. Fodder yield in sorghum is mainly affected by row spacing and seed rate [11]. To expand the utility of sorghum and corn as forage crops, breeders have focused on traits likely to affect its yield and forage quality [12].

Until recently little research has been done in forage productivity of sorghum especially on Sugar graze and Jumbo plus hybrid varieties in Sri Lanka. Hence, the present investigation was undertaken

- To assess the forage productivity and nutritive value of two multi-cut Sorghum hybrid varieties which were recently introduced to the dry zone of Sri Lanka viz. Sugar graze and Jumbo plus.

- To study the growth parameters of Sugar graze and Jumbo plus

- To study the performance of Sugar graze and Jumbo plus in terms of dry matter yield and chemical composition

- To study the effect of spacing on the performance of Sugar graze and Jumbo plus.

\section{Materials and methods Location}

The study was carried out at the livestock farm of the Department of Animal Science, Faculty of Agriculture, Ariviyal Nagar, Kilinochchi. This falls in the Northern Province and dry zone of Sri Lanka. The longitude of the location is $80^{\circ} 39^{\prime} \mathrm{E}$, and latitude is $09^{\circ} 38^{\prime} \mathrm{N}$. The Northern Province tends to be hot and dry in the dry season (Feb. to Sept.), and moderately cool and wet in the wet season (October to January). The soil type on the location is red-yellow latosol.

\section{Planting material}

The planting materials used in this study were 2 cultivars of fodder sorghum, viz. Sugar graze and Jumbo plus.

\section{Experimental design}

Treatments were arranged in factorial completely randomised block design, with 3 replicates. Treatments included 2 cultivars, viz. Sugar Graze and Jumbo Plus with 3 spacings ( $15 \times 30,15 \times 45,15 \times 60 \mathrm{~cm}$ ). Plot size was arranged in such a way to have 64 plants per plot with respective spacing. Basal dressing was done at the rate of $50 \mathrm{~kg}$ urea, $25 \mathrm{~kg}$ triple superphosphate and 1 $2.5 \mathrm{~kg}$ muriate of potash/acre. Seeds were sown at the rate of 2 per hill in March 2016. Seedlings were thinned to a single plant per hill 2 weeks after sowing. One month after planting top dressing was done at the rate of $50 \mathrm{~kg}$ urea and $12.5 \mathrm{~kg}$ Muriate of Potash/acre. Irrigation was done once in 4 days. At the initial stage, manual weeding was done to reduce competition from weeds.

\section{Data collection \\ Growth parameters}

Sixty days after planting the growth parameters, viz. plant height, leaf area, leaf length, leaf width, stem girth, number of leaves per plant, were measured for each cultivar at different spacing.

\section{Fresh and dry matter determination}

Harvesting was done 60 days after planting. Forage was cut $15 \mathrm{~cm}$ above ground, and soon after harvest fresh matter yield per plot was taken. Ten plants from each plot were sampled to determine dry matter weight and to prepare samples for chemical analysis. For dry matter determination, $2 \mathrm{~kg}$ of chopped (1-2 cm long) samples were air-dried for 2 days and oven-dried at $80^{\circ} \mathrm{C}$ till constant weight was reached.

\section{Chemical composition}

After dry matter determination, from each sample, $100 \mathrm{~g}$ of ground sub-samples were taken for chemical analysis and packed in polyethene bags till analysis. Crude fibres $(\mathrm{CF})$, acid detergent fibre (ADF) and neutral detergent fibre (NDF) were determined in the laboratory on dry matter basis by method of [13]. Crude protein was determined on dry matter basis as per standard procedure [14].

\section{Data analysis}

Data were subjected to analysis of variance, and mean separation was done with Duncan's multiple range test by SAS 9.1.3 software. 


\section{Results}

Weather parameters

The air temperature and precipitation (30 days average values) that prevailed at the experimental site during the growing period between March and May 2016 are presented in Table 1. Though unexpected heavy rainfall was experienced in May, the harvest of the current study was completed before the commencement of heavy rainfall.

\section{Vegetative growth parameters}

In terms of plant morphology, the 2 cultivars generally responded differently to variation in plant spacing (Table 2). Except plant height and stem diameter, all other parameters did not differ significantly at different spacing for both cultivars, for which plant height significantly decreased with increasing spacing. In general, the thickest stems were produced at the wider spacing and the thinnest at the narrower spacing. Plant height, inter-node elongation and number of leaves per plant were unaffected by cultivars. In contrast, there were significant differences between cultivars for leaf length, leaf width, leaf area and stem diameter. For all 4 parameters, Sugar graze had significantly higher value than Jumbo plus (Table 3).

\section{Dry matter yield}

Sugar graze produced higher dry matter yields than Jumbo plus (Table 4). Dry matter yields were inversely related to plant spacing with yield decreasing

Table 1 Monthly weather parameters during the study period. Source: Meteorology Department, Vavuniya, Department of Irrigation, Iranamadu (2016)

\begin{tabular}{llc}
\hline Parameter & Mean temperature $\left({ }^{\circ} \mathbf{C}\right)$ & Total rainfall $(\mathbf{m m})$ \\
\hline March & 29.4 & 1.6 \\
April & 31.4 & 16.2 \\
May & 32.1 & 478.1 \\
\hline
\end{tabular}

Table 3 Effects of variety on growth parameters 60 days after planting

\begin{tabular}{lcc}
\hline Growth parameters & $\begin{array}{l}\text { Sugar graze } \\
\text { (mean } \pm \text { SD) }\end{array}$ & $\begin{array}{l}\text { Jumbo } \\
\text { plus (mean } \pm \text { SD) }\end{array}$ \\
\hline Height $(\mathrm{cm})$ & $205.68 \pm 17.34^{\mathrm{a}}$ & $197.48 \pm 22.52^{\mathrm{a}}$ \\
Leaf length $(\mathrm{cm})$ & $94.04 \pm 1.41^{\mathrm{a}}$ & $88.98 \pm 2.68^{\mathrm{b}}$ \\
Leaf width $(\mathrm{cm})$ & $9.21 \pm 0.88^{\mathrm{a}}$ & $6.36 \pm 0.46^{\mathrm{b}}$ \\
Leaf area $\left(\mathrm{cm}^{2}\right)$ & $865.39 \pm 73.49^{\mathrm{a}}$ & $565.51 \pm 30.25^{\mathrm{b}}$ \\
Stem girth $(\mathrm{cm})$ & $10.19 \pm 0.32^{\mathrm{a}}$ & $8.14 \pm 0.55^{\mathrm{b}}$ \\
$\begin{array}{l}\text { Inter-node elongation } \\
\text { (cm) }\end{array}$ & $21.32 \pm 0.55^{\mathrm{a}}$ & $19.43 \pm 0.81^{\mathrm{a}}$ \\
$\begin{array}{l}\text { Number of leaves per } \\
\text { plant }\end{array}$ & $14.4 \pm 0.43^{\mathrm{a}}$ & $14.13 \pm 0.44^{\mathrm{a}}$ \\
\hline
\end{tabular}

a,b Within a row, means without a common superscript differ $(P<0.05)$

progressively as plant spacing increased and the differences were significant (Table 5).

\section{Nutritive value}

Table 6 shows the proximate composition of Sugar graze and Jumbo plus, 60 days after planting. Proximate composition was not influenced by cultivar and spacing.

\section{Discussion \\ Plant height}

Plant height as a growth parameter is a result of elongation of the stem internodes, which is influenced by the environment as suggested by Hozumi et al. [15]. In the current study, taller plants were observed with narrow spacing, which is in agreement with reports in the literature that narrower spacing will give taller plants as a result of competition for sunlight [16]. Taller plants led to narrower stem diameter as well.

The plant height observed in the current study for Sugar graze with $15 \mathrm{~cm} \times 60 \mathrm{~cm}$ spacing is in agreement with the value $(188.833 \pm 1.922 \mathrm{~cm})$ reported by Pahuja et al. [17] in India. The plant height at the spacing $15 \mathrm{~cm} \times 30 \mathrm{~cm}$ was similar to the value $(218 \mathrm{~cm})$

Table 2 Effects of row spacing on growth parameters and yields of Sugar graze and Jumbo plus 60 days after planting

\begin{tabular}{|c|c|c|c|c|c|c|}
\hline \multirow[t]{2}{*}{ Growth parameters } & \multicolumn{3}{|l|}{ Sugar graze } & \multicolumn{3}{|l|}{ Jumbo plus } \\
\hline & $15 \times 30 \mathrm{~cm}$ & $15 \times 45 \mathrm{~cm}$ & $15 \times 60 \mathrm{~cm}$ & $15 \times 30 \mathrm{~cm}$ & $15 \times 45 \mathrm{~cm}$ & $15 \times 60 \mathrm{~cm}$ \\
\hline Height (cm) & $222.93 \pm 6.45^{\mathrm{a}}$ & $203.26 \pm 13.9^{b}$ & $190.86 \pm 13.57^{c}$ & $221.0 \pm 13.01^{\mathrm{a}}$ & $196.93 \pm 10.34^{b}$ & $174.53 \pm 11.53^{c}$ \\
\hline Leaf length (cm) & $95.26 \pm 1.13^{\mathrm{a}}$ & $93.73 \pm 1.20^{\mathrm{a}}$ & $94.13 \pm 0.65^{\mathrm{a}}$ & $89.73 \pm 2.41^{\mathrm{a}}$ & $86.73 \pm 2.44^{\mathrm{a}}$ & $90.70 \pm 1.55^{\mathrm{a}}$ \\
\hline Leaf width (cm) & $8.66 \pm 0.07^{\mathrm{a}}$ & $8.80 \pm 0.72^{\mathrm{a}}$ & $8.60 \pm 0.21^{\mathrm{a}}$ & $6.03 \pm 0.04^{\mathrm{a}}$ & $6.92 \pm 0.14^{\mathrm{a}}$ & $6.14 \pm 0.37^{\mathrm{a}}$ \\
\hline Leaf area $\left(\mathrm{cm}^{2}\right)$ & $824.9 \pm 11.77^{\mathrm{a}}$ & $861.04 \pm 8.27^{\mathrm{a}}$ & $810.24 \pm 25.61^{\mathrm{a}}$ & $540.96 \pm 10.93^{\mathrm{a}}$ & $559.00 \pm 15.90^{\mathrm{a}}$ & $556.57 \pm 24.11^{\mathrm{a}}$ \\
\hline Stem girth $(\mathrm{cm})$ & $9.93 \pm 0.46^{b}$ & $10.44 \pm 0.083^{\mathrm{a}}$ & $10.2 \pm 0.1^{\mathrm{a}}$ & $7.42 \pm 0.27^{b}$ & $8.27 \pm 0.04^{\mathrm{a}}$ & $8.69 \pm 0.06^{\mathrm{a}}$ \\
\hline Inter-node elongation (cm) & $21.3 \pm 0.75^{\mathrm{a}}$ & $21.1 \pm 0.66^{\mathrm{a}}$ & $21.5 \pm 0.36^{\mathrm{a}}$ & $19.83 \pm 0.51^{\mathrm{a}}$ & $19.93 \pm 0.30^{\mathrm{a}}$ & $18.52 \pm 0.69^{\mathrm{a}}$ \\
\hline Number of leaves/plant & $14.66 \pm 0.23^{\mathrm{a}}$ & $14.13 \pm 0.57^{\mathrm{a}}$ & $14.6 \pm 0.34^{\mathrm{a}}$ & $13.936 \pm 0.30^{\mathrm{a}}$ & $13.86 \pm 0.30^{\mathrm{a}}$ & $14.6 \pm 0.34^{\mathrm{a}}$ \\
\hline
\end{tabular}

$\mathrm{a}, \mathrm{b}, \mathrm{c}$ Within a row, means without a common superscript differ $(P<0.05)$ 
Table 4 Effects of variety on dry matter yield 60 days after planting

\begin{tabular}{lc}
\hline Variety & Dry matter yield $(\mathbf{t} / \mathbf{h a})$ \\
\hline Sugar graze & $13.074 \pm 2.17^{\mathrm{a}}$ \\
Jumbo plus & $9.998 \pm 1.89^{\mathrm{b}}$ \\
\hline
\end{tabular}

a,b Within a column, means without a common superscript differ $(P<0.05)$

Table 5 Effect of row spacing on dry matter yield 60 days after planting

\begin{tabular}{ll}
\hline Spacing & Dry matter yield (t/ha) \\
\hline $15 \mathrm{~cm} \times 30 \mathrm{~cm}$ & $14.03^{\mathrm{a}}$ \\
$15 \mathrm{~cm} \times 45 \mathrm{~cm}$ & $10.82^{\mathrm{b}}$ \\
$15 \mathrm{~cm} \times 60 \mathrm{~cm}$ & $9.76^{\mathrm{c}}$ \\
\hline
\end{tabular}

a,b,c Within a column, means without a common superscript differ $(P<0.05)$

reported by Epasinghe et al. [18] in the wet zone of Sri Lanka for Sugar graze, 60 days after planting where the spacing was not mentioned. Similarly [19] in wet zone of Sri Lanka reported lower value $(213.5 \mathrm{~cm})$ for Sugar graze and higher value $(236.5 \mathrm{~cm})$ for Jumbo plus where too the spacing was not mentioned. The plant height observed under spacing of $15 \mathrm{~cm} \times 60 \mathrm{~cm}$ is similar to the value $(191.1 \mathrm{~cm})$ reported by Bandara et al. [20] in the wet zone of Sri Lanka for Sugar graze.

\section{Stem girth}

As far as the stem girth is concerned, the value observed for both varieties was higher than the range (0.01$0.05 \mathrm{~m}$ ) reported for sweet sorghum in Portugal [21]. The current values were also higher than the mean stem girth $(5.38 \pm 0.15 \mathrm{~cm})$ reported by Pahuja et al. [17] in a trial to evaluate 17 forage sorghum hybrids and 6 check varieties in India. The differences may be due to climatic condition, soil fertility and stage of maturity of the plants. In the current study, stem girth was affected by cultivars which is in agreement with the findings of Yousef et al. [22] and Ayub et al. [23] who reported a significant variation in stem girth among different cultivars of sorghum.

\section{Leaf length, leaf width and leaf area}

Leaf development has been described extensively for fodders, as growth is mostly reflected in large increase in leaf length as plants grow to maturity, accompanied by relatively small increase in width and thickness [24]. Large leave lengths are also important for the survival of individual plants within a sward [25]. In the current study, leaf length, leaf width and leaf area were unaffected by spacing within cultivar. The higher values for leaf length, leaf width and leaf area of Sugar graze than Jumbo plus are attributed to the genetic effect of these cultivars. Leaf length of Sugar graze was similar to the value $95 \pm 2.0 \mathrm{~cm}$ reported by Pahuja et al. [17] in India for the first cut at $50 \%$ flowering and a spacing of $15 \times 45 \mathrm{~cm}$, whereas leaf width was higher than that recorded by the same authors $(6 \pm 0.58 \mathrm{~cm})$.

The higher mean leaf area in Sugar graze than Jumbo plus in the current study may be attributable to genetic makeup of the cultivars [26-31] also observed variation in leaf area among various cultivars and varieties of forage sorghum.

\section{Dry matter yield}

Plant spacing has a marked impact on the efficiency of use of land, light, water and nutrients. By optimising plant spacing, highest yield potential can be achieved from the smallest possible area [32]. Significantly higher dry matter yield of Sugar graze is due to its genotype, and the growth parameters contributed for the higher yield were the higher values of leaf length, leaf width and stem girth than for the Jumbo plus. Erandathi et al. [19] and Bandara et al. [20] in the wet zone of Sri Lanka reported 6.6 and $6.01 \mathrm{t} / \mathrm{ha}$ dry matter yield, respectively, for Sugar graze where the harvesting was done at 50\% flowering stage. Erandathi et al. [19] also reported the dry matter yield of $5.1 \mathrm{t} / \mathrm{ha}$ for Jumbo plus. Current values of dry matter yield of both were higher than the above values recorded in the wet zone of Sri Lanka. Similar value of the dry matter yield of current study was reported for Sugar graze in the wet zone of Sri Lanka [18] where the harvesting was done 60 days after planting as in the current study. Chaudhry et al. [26] recorded yields of $10,400-13,100 \mathrm{kgDM} / \mathrm{h}$ for advanced lines of forage sorghums and [33] recorded 13,262 $\mathrm{kgDM} / \mathrm{ha}$ at $15 \mathrm{~cm}$ row spacing 78 days after sowing for Sugar graze. The differences in the dry matter yield of cultivars of the present study with the literature are attributed to differences in the spacing, soil fertility, and environmental conditions.

Table 6 Proximate composition of Sugar graze and Jumbo plus 60 days after planting

\begin{tabular}{|c|c|c|c|c|c|}
\hline Variety & $\mathrm{DM} \%$ (mean $\pm \mathrm{SD})$ & CF\% (mean \pm SD) & NDF\% (mean \pm SD) & $\mathrm{ADF}($ mean $\pm \mathrm{SD})$ & $C P($ mean $\pm S D)$ \\
\hline Sugar graze & $17.91 \pm 0.95^{\mathrm{a}}$ & $29.22 \pm 3.59^{a}$ & $69.360 \pm 5.33^{a}$ & $47.08 \pm 5.57^{\mathrm{a}}$ & $8.77 \pm 1.35^{\mathrm{a}}$ \\
\hline Jumbo plus & $17.26 \pm 1.16^{\mathrm{a}}$ & $31.09 \pm 3.33^{a}$ & $70.578 \pm 4.06^{a}$ & $45.54 \pm 2.9^{a}$ & $7.52 \pm 0.33^{a}$ \\
\hline
\end{tabular}

${ }^{a}$ Within a column, means without a common superscript differ $(P<0.05)$ 
Significant reduction in dry matter yield with increasing plant spacing may be due to decreasing plant density with increasing spacing. In a study conducted at Kemptville Research Station, Canada [34], planting density had a significant effect on fresh and dry matter production and two higher densities had significantly higher production than the 2 lower densities for 3 sweet sorghum hybrids including Sugar graze. In maize, total forage mass was greater at higher plant densities than at lower plant densities, but forage mass was not different among plant populations that exceeded 58,130 plants/ha [35]. Forage dry matter yield declined linearly from 10.9 to $8.1 \mathrm{Mg} / \mathrm{ha}$ as within-row spacing increased from 50 to $60 \mathrm{~cm}$ in Sorghum [36].

The dry matter percentage of Jumbo plus was higher than the values (15.9\%) reported by Tauqir et al. [37] in Pakistan and [18] in Sri Lanka who reported a dry matter percentage of $12.66 \%$ for Sugar graze 45 days after planting. The low dry matter percentage of the latter may be due to 15 days early harvesting than the current study.

The crude fibre percentage of this study is in agreement with the finding of Epasinghe et al. [18] in Sri Lanka who reported CF\% of 32.23 for Sugar graze 60 days after planting. Higher value of $36.8 \%$ was reported by Bandara et al. [20] in the wet zone of Sri Lanka at 50\% flowering stage for Sugar graze, whereas lower value (25.12\%) was reported by Bozorgvar et al. [12] for Sugar graze in Iran. The differences may be due to stage of maturity and soil fertility.

The NDF\% of this study was similar to the finding of Epasinghe et al. [18] (2012) in Sri Lanka where the NDF\% was 67.55 for Sugar graze 60 days after planting in the wet zone of Sri Lanka. Similar values NDF for Sugar graze and Jumbo plus were reported in Turkey [38]; the values were 67.97 and $74.89 \%$ for Sugar graze and Jumbo plus, respectively. But the result for Sugar graze was higher than the finding of Davison [39] in Manawatu, New Zealand, as he stated that NDF\% of Sugar graze was $65.2,78$ days after sowing. For Jumbo plus cultivar, observed value was lower than related study [35] in Pakistan (75.2\%). The differences may be due to stage of maturity at harvesting, soil fertility and other environmental factors.

The ADF\% of this study was higher than the finding in Sri Lanka [18] reporting the ADF\% for Sugar graze as 40.12, 60 days after planting. The current result for Sugar graze was higher than the finding in Manawatu, New Zealand [39], stating that ADF \% of Sugar graze was 36.2 after 78 days of sowing. For Jumbo plus cultivar, observed value (39.7) was higher than related study in Pakistan [2]. But for Jumbo plus cultivar, observed value $(48.32 \%)$ was in agreement with related study in Turkey [34], but the value (41.86) reported for Sugar graze was lower than the current study.
The CP\% of this study was lower than the finding in Sri Lanka [18] reporting that CP\% for Sugar graze was 17.2, 60 days after planting; also the result for Sugar graze was lower than the finding in Manawatu, New Zealand [37], stating that $\mathrm{CP} \%$ of Sugar graze was 10.2 after 78 days of sowing. A lower value (7.45) than the current study was reported in Iran [12].

For Jumbo plus, observed $\mathrm{CP}$ value was lower than (11.05) the related study in Pakistan [37]. But for Jumbo plus and Sugar graze, observed values were in agreement with related study in Turkey [38] where the values reported were 7.2 and $6.82 \%$ at milking stage, respectively. The differences may be attributed to differences in soil fertility, stage of maturity and other environmental factors.

From the above discussion, Sugar graze showed significantly higher values for the growth parameters stem girth, leaf length, leaf width and leaf area than Jumbo plus. Sugar graze showed significantly higher dry matter yield than Jumbo plus. Dry matter yield was inversely related to spacing, and the narrowest spacing gave the highest dry matter yield. Nutritive value was unaffected by cultivar and spacing within cultivar.

\section{Conclusions}

Therefore, it can be concluded that Sugar graze with $15 \times 30 \mathrm{~cm}$ could be used to get maximum yield in the dry season with irrigation in the dry zone of Sri Lanka.

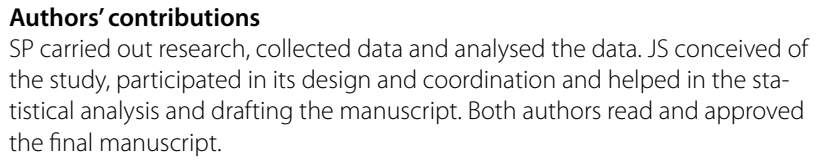

SP carried out research, collected data and analysed the data. JS conceived of the study, participated in its design and coordination and helped in the statistical analysis and drafting the manuscript. Both authors read and approved the final manuscript.

\section{Competing interests}

The authors declare that they have no competing interests.

\section{Availability of data and materials}

The datasets used and/or analysed during the current study are available from the corresponding author on reasonable request.

\section{Consent for publication}

Not applicable.

\section{Ethics approval and consent to participate}

Not applicable.

Funding

No funding was obtained.

\section{Publisher's Note}

Springer Nature remains neutral with regard to jurisdictional claims in published maps and institutional affiliations.

Received: 28 August 2017 Accepted: 26 February 2018

Published online: 09 March 2018 


\section{References}

1. Sarwar M, Khan MA, labal Z. Feed resources for livestock in Pakistan. Int Agric Biol. 2002;2002(4):186-92.

2. Sivayoganathan B. The SOLID approach to producing year-round cattle feed. USAID; 2017. p. 68

3. Keshavarz Afshar R, Chaichi MR, Asareh MH, Hashemi M, Liaghat A. Interactive effect of deficit irrigation and soil organic amendments on seed yield and flavonolignan production of milk thistle (Silybum marianum $\mathrm{L}$. Gaertn.). Ind Crops Prod. 2014;58:166-72.

4. Jahanzad E, Jorat M, Moghadam H, Sadeghpour A, Chaich MR, Dashtaki M. Response of a new and a commonly grown forage sorghum cultivar to limited irrigation and planting density. Agric Water Manag. 2013;117:62-9.

5. Keshavarz Afsha R, Ansari Jovini M, Chaichi MR, Hashemi M. Grain sorghum response to Arbuscular mycorrhiza and phosphorous fertilizer under deficit irrigation. Agron J. 2014;106(4):1212-8.

6. Amer S, Hassanat F, Berthiaum R, Seguin P, Mustafa AF. Effects of water soluble carbohydrate content on ensiling characteristics, chemical composition and in vitro gas production of forage millet and forage sorghum silages. Anim Feed Sci Technol. 2012;177:23-9.

7. Jaster EH, Fisher CM, Miller DA. Nutritive value of oatlage. barley/pea, pea, oat/pea, pearl millet, and sorghum as silage grown under a double cropping forage system for dairy heifers. J Dairy Sci. 1985;68:2914-21.

8. Singh BR, Singh DP. Agronomic and physiological responses of sorghum, maize and pearl millet to irrigation. Field Crop Res. 1995;42:57-67.

9. CGIAR. Sorghum. CGIAR. 2013. http://www.cgiar.org/ourresearch/cropfactsheets/sorghum/. Accessed 10 Feb 2016.

10. Newman Y, Erickson J, Vermerris W, Wright D. Forage sorghum (Sorghum bicolor): overview and management. No.SS-AGR-333. IFAS Extension. University of Florida, USA; 2013.

11. Scott S, Gordon B, Taylor R, Duncan S, Fjell D. Narrow-row grain sorghum production in Kansas. Manhattan: Kansas State University; 1999. p. 1-4.

12. Bozorgvar N, Khademosharich MM, Neamatollahi E, Jahansuz MR Determine the best varieties of forage sorghum. Adv Environ Biol. 2013;7(6):1105-12.

13. Van Soest PJ, Robertson JB, Lewis BA. Methods for dietary fiber, neutral detergent fiber and non-starch polysaccharides in relation to animal nutrition. J Dairy Sci. 1991;74:3583-97.

14. AOAC. Official methods of analysis. 18th ed. Washington: Association of Official Analytical Chemists; 2005.

15. Hozumi E, Weston $\mathrm{RH}$, Hesketh J. Factors limiting the intake of feed by sheep: studies with wheat hay. Aust J Agric Res. 1965;18:983-1002.

16. Lamana MCL. Effect of spacing between plants on growth and forage yield of two maize (Zea mays L.) cultivars. Masters Dissertation. University of Khartoum; 2003.

17. Pahuja S, Arya S, Kumari S, Panchta R. Evaluation of forage sorghum hybrids [Sorghum bicolor (I.) Moench]. Forage Res 2014;40(3):159162. [cited 25 Jan 2016]. http://forageresearch.in/wpcontent/ uploads/2014/12/159-162.pdf.

18. Epasinghe TM, Jayawardena VP, Premalal GGC. Comparison of growth, yield and nutritive value of maize, multi-cut fodder sorghum and hybrid Napier (var. Co3) grown in wet zone of Sri Lanka. In: Proceedings of 22nd Annual Students Research Session, Department of Animal Science; 2012. [cited 12 Feb 2016]. http://agri.pdn.ac.Ik/dept/pdf/Proceedings\%20-\%20 2012\%20As.pdf.

19. Erandathi SAT, Premaratne S, Premalal GGC. Yield, chemical composition and adverse factors of different varieties of sorghum (Sorghum bicolour (L.) Moench) and hybrid var.CO-3 (Pennisetum americanum $\times$ Pennisetum Purpureum) in the mid country of Sri Lanka. In: Proceedings of 23rd annual students research session, Department of Animal Science, Faculty of Agriculture, University of Peradeniya; 2013. p. 17-18.
20. Bandara PGG, Premalal GGC, Nayananjalie WAD. Assessment of nutritive value of sorghum (Sorghum bicolor (L.) Moench) fodder in Sri Lanka. Int J Livest Res. 2016;6(8):44-9.

21. Jose S, Tomas M, Bohumil H, Tatiana I. Sweet sorghum (Sorghum bicolour (L.) Moench) bio energy value-importance for Portugal. Agric Trop Subtrop. 2012;45(1):12-9.

22. Yousef E, Carmi A, Nikbachat M, Zenou A, Umiel N, Miron J. Characteristics of tall versus short-type varieties of forage sorghum grown under two irrigation levels, for summer and subsequent fall harvests, and digestibility by sheep of their silages. Anim Feed Sci Technol. 2009;152:1-11.

23. Ayub M, Tanveer A, Mahmud K, Ali A, Azam M. Effect of nitrogen and phosphorus on the fodder yield quality of two sorghum cultivars (Sorghum bicolor L.). Pak J Biol Sci. 1999;2:247-50.

24. Skinner RH, Nelson CJ. Role of leaf appearance rate and the coleoptiles tiller in regulating tiller production. Crop Sci. 1994;34:71-5.

25. Barre $P$, Turner $L B$, Gutierrez AJE. Leaf length variation in perennial forage grasses (Review). Agriculture. 2015;5:682-96.

26. Chaudhry GN, Riaz M, Ahamad G. Comparison of advanced lines of Sorghum bicolor (L.) Moench for green fodder and dry matter yield and morpho-economic parameters. J Agric Res. 2006:44:191-6.

27. Musa M, Gondal MR, Ali A, Ashraf M. Effect of cutting at different plant growth stages and heights above ground levels on green fodder and dry matter yields of Sadabahar. J Agric Res. 1993;31:409-13.

28. Naeem M, Chauhan MSM, Khan AH, Salahaddin S. Evaluation of different varieties of sorghum for green fodder yield potential. Asian J Plant Sci. 2002;1:142-3.

29. Mehmud K, Ahmad I, Ayub M. Effect of nitrogen and phosphorus on the fodder yield and quality of two sorghum (Sorghum bicolor L.) cultivars. Int J Agric Biol. 2003:5:61-3.

30. Chohan MSM, Naeem M, Khan AH, Salah-ud-Din S. Performance of newly developed forage varieties of sorghum (Sorghum bicolor (L.) Moench). J Plant Sci. 2003;2:48-50

31. Chohan MSM, Naeem M, Khan AH, Kainth RA. Performance of pearl millet (Pennisetum americanum L.) varieties for forage yield. J Agric Res. 2006:44:23-7.

32. Oseni TO, Fawusi MO. Influence of nursery spacing and plant arrangement on growth and leaf nutrient content of three citrus root stock seedlings. Trop Agric. 1986;64(1):41

33. Silungwe D, Millner JP, McGill CR. Evaluation of forage yield and quality of sorghum, Sudan-grass and pearl millet cultivars in Manawatu. Masters Thesis. Massey University, New Zealand; 2011.

34. Ashraf T, Alessandro S. Effects of planting density and genetics on production of sweet sorghum. Poster presented at the Northeast Agricultural and Biological Engineering Conference (NABEC), Kemptville, 27-30 July 2014.

35. Cuomo GJ, Redfearn DD, Blouin DC. Plant density effects on tropical corn forage mass, morphology, and nutritive value. Agron J. 1998;90:93-6.

36. Caravetta GJ, Cherney JH, Johnson KD. Within-row spacing influences on diverse sorghum genotypes: II. Dry matter yield and forage quality. Agron J. 1990;82(2):210-5

37. Tauqir NA, Sarwar M, Jabbar MA, Mahmood S. Nutritive value of Jumbo grass (Sorghum bicolour Sorghum sudanefe) silage in lactating Nili-Ravi buffaloes. Cellul Pak Vet J. 2009:29(1):5-10.

38. Uzun F, Ugur S, Sulak M. Yield, Nutritional and chemical properties of some sorghum $\times$ sudan grass hybrids (Sorghum bicolour (L.) Moe$n c h \times$ Sorghum Sudanese Stapf.). J Anim Vet Adv. 2009;8(8):1602-8.

39. Davison S, Plant density effects on tropical corn forage mass, morphology, and nutritive value. M.Sc Thesis, Massey University, Palmerston North, New Zealand; 2011 